\title{
TBT-induced imposex in marine neogastropods is mediated by an increasing androgen level
}

\author{
C. Bettin ${ }^{1}$, J. Oehlmann ${ }^{2}$ \& E. Stroben ${ }^{1}$ \\ ${ }^{1}$ Institut für Spezielle Zoologie und Vergleichende Embryologie, Universität Münster; \\ Hüfferstraße 1, D-48149 Münster, Germany \\ ${ }^{2}$ Lehrstuhl für Umweltverfahrenstechnik, Internationales Hochschulinstitut (IHI) Zittau; \\ Markt 23, D-02763 Zittau, Germany
}

\begin{abstract}
Tributyltin (TBT) exposure at different concentrations $(5,50$, and $100 \mathrm{ng}$ TBT as $\mathrm{Sn} / 1)$ induces a concentration- and time-dependent imposex (= pseudohermaphroditism) development in female Nucella lapillus and Hinia reticulata. In both species the average imposex stage, termed as vas deferens sequence (VDS) index, and the average female penis length increases with increasing TBT concentration and duration of TBT exposure. Testosterone added at a concentration of $500 \mathrm{ng} / \mathrm{l}$ induces a faster and more intensive imposex development compared to that induced by the TBT concentrations used in the present experiments. Radioimmunological determination of endogenous steroid content reveals increasing testosterone titres in female gastropods exposed to TBT which correlate with the TBT concentration used and the duration of the experiment. The most marked and highest increase of the endogenous testosterone level is exhibited by females of both species exposed to testosterone. Simultaneous exposure to TBT and to the antiandrogen cyproterone acetate which suppresses imposex development completely in $N$. lapillus and reduces imposex development strongly in $H$. reticulata proves that the imposex-inducing effects of TBT are mediated by an increasing androgen level and are not caused directly by the organotin compound itself. Furthermore, TBT-induced imposex development can be suppressed in both snails by adding estrogens to the aqueous medium. These observations suggest that TBT causes an inhibition of the cytochrome P-450 dependent aromatase system which catalyses the aromatization of androgens to estrogens. The increase of the androgen content or the shift of the androgen-estrogen balance in favour of androgens induces the development of pseudohermaphroditism in marine prosobranchs. Artificial inhibition of the cytochrome P-450 dependent aromatase system using SH 489 (1-methyl-1,4androstadiene-3,17-dione) as a steroidal aromatase inhibitor and flavone as a nonsteroidal aromatase inhibitor induces imposex development in $N$. lapillus as well as in $H$. reticulata.
\end{abstract}

\section{INTRODUCTION}

The use of tributyltin (TBT) compounds as biocides in antifouling paints and wood preservatives leads to contamination of marine and freshwater environments. TBT has been shown to be highly toxic to a number of aquatic animals including fish (Hall \& Pinkney, 1985; Martin et al., 1989; Fent, 1991; Fent \& Meier, 1992), mussels, oysters (Laughlin et al., 1986; Thain, 1986; Thain \& Waldock, 1986; Langston et al., 1987; Chagot et al., 1990) and crustaceans (Evans \& Laughlin, 1984; Cardwell \& Sheldon, 1986). In marine prosobranch snails, TBT induces reproductive abnormalities and sterilization of female animals. This phenomenon, termed as pseudohermaphroditism (Jenner, 1979) or imposex (Smith, 1971), is characterized by the development of additional male sex organs 
(penis and/or vas deferens and prostate tissue) on females. A first description of imposex was given by Blaber (1970) for Nucella lapillus; he described females with a penis-like outgrowth behind the right ocular tentacle. Meanwhile, TBT-induced pseudohermaphroditism is a widespread phenomenon within the Prosobranchia and has been recorded in 118 species belonging to 63 genera (Fioroni et al., 1991). Since 1970, mainly Ocenebra erinacea (Féral, 1974, 1976a-c, 1980; Oehlmann et al., 1992), Ilyanassa obsoleta (Smith, 1971, 1980, 1981a-d; Bryan et al., 1989) and especially N. lapillus (Féral, 1980; Gibbs et al., 1987, 1988; Oehlmann et al., 1991) and Hinia reticulata (Stroben et al., $1992 a, b)$ have been used as indicator species for TBT biomonitoring. Because of its high TBT sensitivity, $N$. lapillus has declined in many areas of Europe over the past 10 to 15 years (Gibbs \& Bryan, 1986, 1987; Oehlmann et al., 1991).

The intensity of imposex development is characterized by a new classification system (Fig. 1) which is based on the description of Blaber (1970) and distinguishes 6 stages of imposex expression with three different types $(a, b, c)$ in the first three stages and in stage 5, and two types in stage 4 and 6 (Oehlmann et al., 1992; Stroben et al., 1992a). This imposex classification, which is generally valid for the imposex description in all prosobranch species, depends on the presence of a penis, the extension of the vas deferens and an intact vaginal opening. Stage 0 refers to a normal female without any male characteristics. The first symptoms of pseudohermaphroditism as described in stage 1 are a small penis without a penis duct behind the right tentacle (type a), a short distal vas deferens-section also behind the right tentacle (type b) or a short proximal vas deferenssection beginning at the vaginal opening (type c). Depending on the environmental TBT pollution and the sensitivity of each gastropod species, the morphological expression of male sex characteristics increases continuously. Stage 4 , which represents the last fertile stage of imposex, is characterized by a penis with a penis duct and a complete vas deferens either running from the penis over the bottom of the mantle cavity up to the vaginal opening or the vas deferens passes the vaginal opening and runs into the ventral channel of the capsule gland (type $4^{\circ}$ ). In stage 5 , the vagina is either replaced by a small prostate gland (type a) or the vaginal opening is occluded by proliferating vas deferens tissue (type b). In type $c$, the ontogenetic closure of the pallial oviduct is incomplete; either the bursa copulatrix alone or, additionally, the capsule gland are split ventrally for up to two-thirds of its length. From this stage onwards, TBT-induced imposex development leads to reproductive failure and to sterility because copulation is impossible and egg-capsules can neither be released in type a and b nor be produced in type c. In stage 6 , the lumina of the capsule gland and its vestibulum are filled with an accumulation of abortive egg capsules, provoking an intensive swelling of the capsule gland and, finally, often a rupture causing the death of the animal. As a consequence of high TBT exposure in early life stages, a sex change might occur in the dogwhelk N. lapillus (Gibbs et al., 1988; Oehlmann et al., 1991) and in Ocinebrina aciculata (Fioroni et al., 1991; Oehlmann et al., 1996), which is characterized by a suppressed oogenesis and a commenced spermatogenesis.

Although the morphological aspects of TBT-induced pseudohermaphroditism have been investigated intensively in many prosobranch species by different research groups (Fioroni et al., 1991), the detailed biochemical mechanism of this phenomenon has remained obscure. Féral \& Le Gall (1983) demonstrated in female Ocenebra erinacea an alteration of the neurosecreta of the pedal ganglia after TBT-exposure which induces 


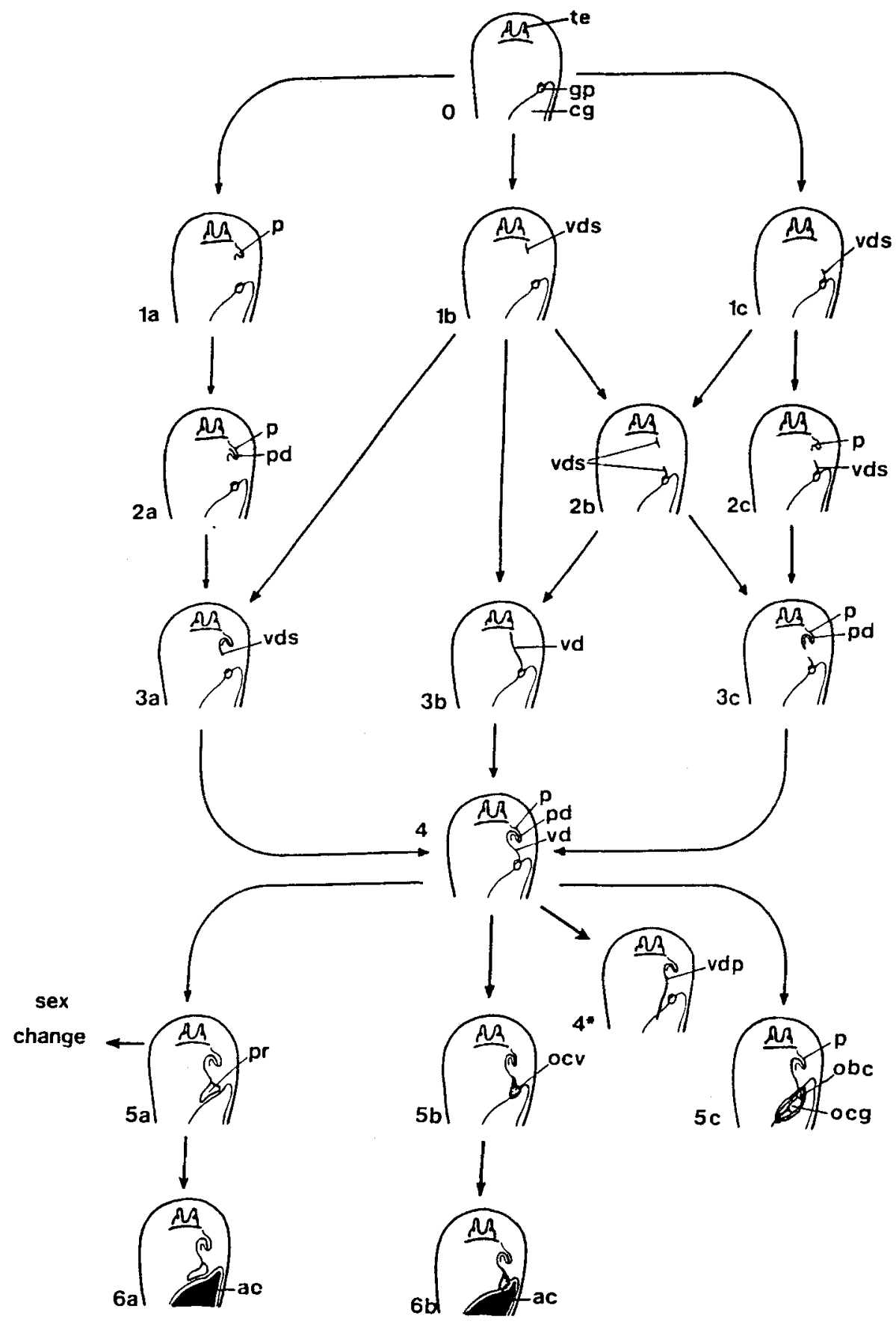

Fig. 1. General scheme of imposex evolution in prosobranchs. Abbreviations: ac, aborted capsules; $\mathrm{cg}$, capsule gland; gp, genital papilla; obc, open bursa copulatrix; ocg, open capsule gland; ocv, occlusion of the vulva; p, penis; pd, penis duct; pr, prostate; te, tentacle; vd, vas deferens; vdp, vas deferens passage into capsule gland; vds, vas deferens section 
development of a penis and vas deferens-sections. Our own radioimmunological determinations of sexual hormones in unaffected and affected females suggest the involvement of steroids in the expression of imposex (Stroben et al., 1991). Pure females display the lowest testosterone content, whereas advanced imposex stages have the highest testosterone content. Similar results in the dogwhelk were obtained by Spooner et al. (1991). These findings gave occasion for further experiments to investigate the influence of TBT on the steroid metabolism in $H$, reticulata and $N$. lapillus.

\section{MATERIALS AND METHODS}

All experiments were conducted with Nucella lapillus and Hinia reticulata. Because of the widespread coastal TBT pollution, it is virtually impossible to find populations of both species in Europe which are totally unaffected by imposex. The experimental specimens were collected in low-polluted areas of the French coast, in Méan Mélen $(N$. lapillus) and Pointe de Pléneuf ( $H$. reticulata) where about 50 to $90 \%$ of the females already exhibit imposex development that was, however, still at a moderate stage.

For the laboratory experiments, a 24 - to 48 -h static renewal system in 80 -litre glass aquaria provided with Eheim power filters and artificial seawater (salinity $35 \%$ was used. The natural temperature fluctuations at Roscoff (Brittany, France; $8.5^{\circ} \mathrm{C}$ in winter, $16{ }^{\circ} \mathrm{C}$ in summer) were imitated. The experiments with application of different TBT concentrations and testosterone were run under a constant photoperiod of 12:12 (L:D), whereas all other experiments were carried out under natural light conditions according to season. For every experiment, 200 to 250 snails of each species were kept in two connected aquaria, and a tide simulation system was employed.

Experime n 1 . To examine the concentration-dependent relationship between TBT exposure and imposex development, $N$. lapillus and $H$. reticulata were exposed for 6 months to TBT at concentrations of 5,50 , or $100 \mathrm{ng}$ as $\mathrm{Sn} / \mathrm{l}$.

Experiment 2 . To investigate an imposex-inducing capability of androgens, the gastropods were exposed in this experiment for 5 months to testosterone at a concentration of $500 \mathrm{ng} / \mathrm{l}$.

Experiment 3 . To prove whether the imposex-inducing effects of TBT are mediated by androgens, the snails were simultaneously exposed for 5 months to a TBT concentration of $50 \mathrm{ng}$ as $\mathrm{Sn} / \mathrm{l}$ with and without $1.25 \mathrm{mg} / \mathrm{l}$ cyproterone acetate. The antiandrogen cyproterone acetate reduces free androgen binding sites by competitively blocking the androgen receptors without causing androgen effects.

Experime $\mathrm{t} 4$. To study the influence of estrogens in TBT-induced pseudohermaphroditism, $N$. lapillus and $H$. reticulata were kept for 5 months in seawater which contained $50 \mathrm{ng} \mathrm{TBT}$ as $\mathrm{Sn} / 1$ with and without $1 \mu \mathrm{g} / 1$ of an estrone and $17 \beta$-estradiol mixture (1:1).

Experiment 5 . In this experiment, the effects of the specific aromatase inhibitor SH 489 and of the non-specific aromatase inhibitor flavone on both gastropods were studied. SH 489 (1-methyl-1,4-androstadiene-3,17-dione) used at a concentration of 0.3 $\mathrm{mg} / \mathrm{l}$ for 5 months belongs to the group of compounds which cause a competitive and irreversible inhibition of the cytochrome P-450 dependent aromatization of androgens to estrogens (Henderson, 1987). Flavone was used at a concentration of $2.7 \mathrm{mg} / \mathrm{l}$ seawater.

The analyses were conducted at monthly intervals (sample size 30 specimens) with 
an additional sample 2 weeks after starting the experiments. The specimens were narcotized in a solution of $7 \% \mathrm{MgCl}_{2}$ in distilled water. After cracking the shell with a vice, the external properties of the genital tract including vas deferens extension and penis length were measured to the nearest $0.1 \mathrm{~mm}$. For imposex classification the snails were sexed; the penis and vas deferens extension were measured and the imposex stage according to Stroben et al. (1992a) determined. As imposex indices, the VDS (vas deferens sequence) index as the average imposex stage of a population and the average female penis length were calculated.

\section{Reagents}

All solvents used for extraction and purification were p.a. grade and were obtained either from Merck, Germany or J. T. Baker, Netherlands. Cyproterone acetate and SH 489 (1-methyl-1,4-androstadiene-3,17-dione) were generously supplied by Schering, Germany. Flavone (2-phenyl-4H-1-benzopyran-4-one) was purchased from Sigma, Germany. Tritiated steroids employed for the estimation of extraction recovery were purchased from bio Mérieux, France. Endogenous steroids of the snails were measured after extraction by radioimmunoassays with ${ }^{125} \mathrm{~J}$ labelled tracers using the Clinical Assay ${ }^{\mathrm{TM}}$ (Sorin Biomedica, Italy) for the determination of $17 \beta$-estradiol and the Double Antibody Assay (Diagnostic Products Corporation, USA) for the estimation of testosterone. To approximate the matrix effects of the measurement, the standards of the 17B-estradiol assay which were dissolved in human serum were replaced by our own standards in borate buffer ranging from 0.25 to $25 \mathrm{pg} 17 \beta$-estradiol per tube. Radioimmunological determination of the steroids was carried out in duplicate according to the instructions of the manufacturers. Since the testosterone antiserum reacts not only with testosterone but also with dihydrotestosterone ( $34 \%$ cross-reactivity), this androgen was also registered during the measurement. The cross-reactivity to other naturally occurring steroids was less than $3.8 \%$ for the testosterone antiserum and $0.6 \%$ for the $17 \beta$-estradiol antiserum.

\section{Steroid extraction}

Single weighted specimens were homogenized in $2 \mathrm{ml}$ ethanol and frozen for at least $24 \mathrm{~h}$. Homogenates were extracted at first with $8 \mathrm{ml}$ of diethyl ether and in two further extractions with $10 \mathrm{ml}$ diethyl ether:ethanol $(4: 1, \mathrm{v} / \mathrm{v})$ for $10 \mathrm{~min}$. The solvent extracts were combined and evaporated under a stream of compressed air in a waterbath at $37^{\circ} \mathrm{C}$. After being redissolved in $2 \mathrm{ml} 80 \%$ methanol, the residues were washed twice for $5 \mathrm{~min}$ with $5 \mathrm{ml}$ petroleum ether to remove the lipid fraction. The washed methanol fractions were evaporated to dryness and redissolved in $1 \mathrm{ml}$ borate buffer for radioimmunological determination. Serial dilutions of extracts gave optimum parallelism to the standard curves of the radioimmunoassays used and indicated the suitability of the extraction method which can be used without extracting interfering substances. In order to estimate the extraction efficiency, homogenates were extracted after addition of either ${ }^{3} \mathrm{H}$ labelled testosterone or ${ }^{3} \mathrm{H}$ labelled $17 \beta$-estradiol. An aliquot of each sample was counted after extraction in a liquid scintillation counter. Calculated recovery values were $62.2 \pm 5.04 \%$ for testosterone $(n=9)$, and $84.3 \pm 5.84 \%$ for $17 \beta$-estradiol $(n=9)$. The petroleum ether phase used to remove the lipids contained $3.12 \pm 0.91 \%$ of testosterone and $5.03 \pm 1.03 \%$ of $17 \beta$-estradiol. 


\section{Organotin analysis}

TBT and dibutyltin (DBT) compounds were determined according to Stroben et al. (1992a). One to five specimens were homogenized in stoppered tubes and $10 \mathrm{ml}$ of concentrated $\mathrm{HCl}$ was added. After shaking for $30 \mathrm{~min}$, the tissues were extracted with 10 $\mathrm{ml}$ hexane on an automatic shaker for $30 \mathrm{~min}$ and then centrifuged. TBT as Sn plus DBT as $\mathrm{Sn}$ were measured in the hexane extract using a Perkin-Elmer HGA-500 attached to a Perkin-Elmer 5000 AAS (wave length $224.6 \mathrm{~nm}$; slit $0.7 \mathrm{~nm}$; injection volume $25 \mu \mathrm{l}$ ). A background correction was used. TBT as Sn was determined in the hexane extract after shaking with $3 \mathrm{ml} 1 \mathrm{~N} \mathrm{NaOH}$ for $3 \mathrm{~min}$. Internal standardization (standard addition with spiked samples) was employed. Certified reference material (CRM; PACS-1, delivered by the National Research Council of Canada) was analysed additionally. Our results were within the standard deviation of the certified values of the CRM. Recovery factors were

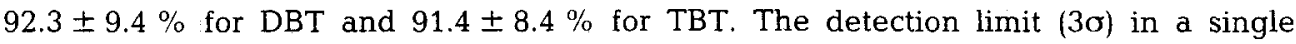
sample was $7.4 \mathrm{ng}$ DBT as Sn and $8.8 \mathrm{ng}$ TBT as Sn.

\section{RESULTS AND DISCUSSION}

Exposure to TBT at different concentrations $(5,50$, and $100 \mathrm{ng}$ TBT as Sn/l) triggers a concentration- and time-dependent imposex development both in female Nucella lapillus and in female Hinia reticulata (Fig. 2). In both species, the average imposex stage of a sample, termed as vas deferens sequence (VDS) index, and the average female penis length increases with increasing TBT concentration and duration of TBT exposure. Testosterone added at a concentration of $500 \mathrm{ng} / \mathrm{l}$ induces in the absence of TBT a faster and more intensive imposex development compared to the applied TBT concentrations of 5 to $100 \mathrm{ng} \mathrm{TBT}$ as $\mathrm{Sn} / \mathrm{l}$.

In comparison with the controls, female gastropods of the TBT exposure groups present increasing endogenous testosterone titres which correlate with the TBT concentration and the duration of the experiment (Fig. 3). After a 2-month exposure, the testosterone values for the highest TBT concentration in $N$. lapillus are significantly different from those of the control; and after four months of exposure, the values for the 50 and $100 \mathrm{ng}$ TBT as Sn/l exposure groups differ from those of the untreated animals. In $H$. reticulata, differences of the testosterone titre from that of the control appear after 4 months exposure in all three TBT-treated groups. After 6 months, both species exhibit a significantly higher testosterone content in all TBT exposure groups compared to the control. A marked and very high increase of the endogenous testosterone level is measured in females of both species exposed to testosterone. The high testosterone values which are significantly different from those of the control group at all monthly intervals account for the advanced imposex development of this experimental group compared to all TBT-exposed animals and indicate the capability of the snails to accumulate steroids from the aqueous environment. A comparison of the endogenous testosterone content and the different imposex stages of both species in the TBT experiments demonstrates that the more advanced imposex stages exhibit higher testosterone levels in the tissue compared to those in pure females (imposex stage 0; cf. Figure 4). All values in $N$. lapillus and all values, with the exception of stage 0 versus stage 1 , in H. reticulata are significantly different from each other. 

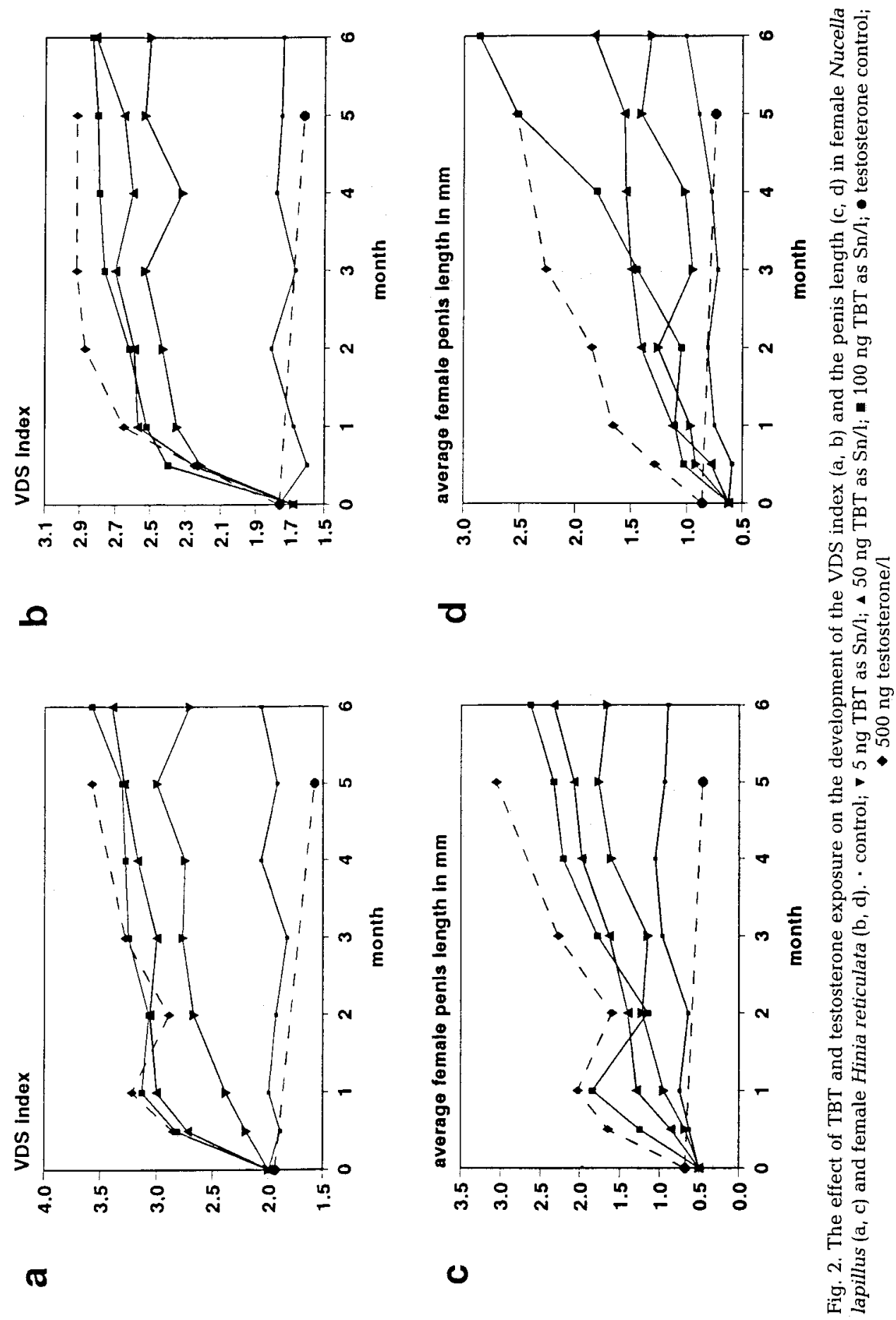

T) 
a

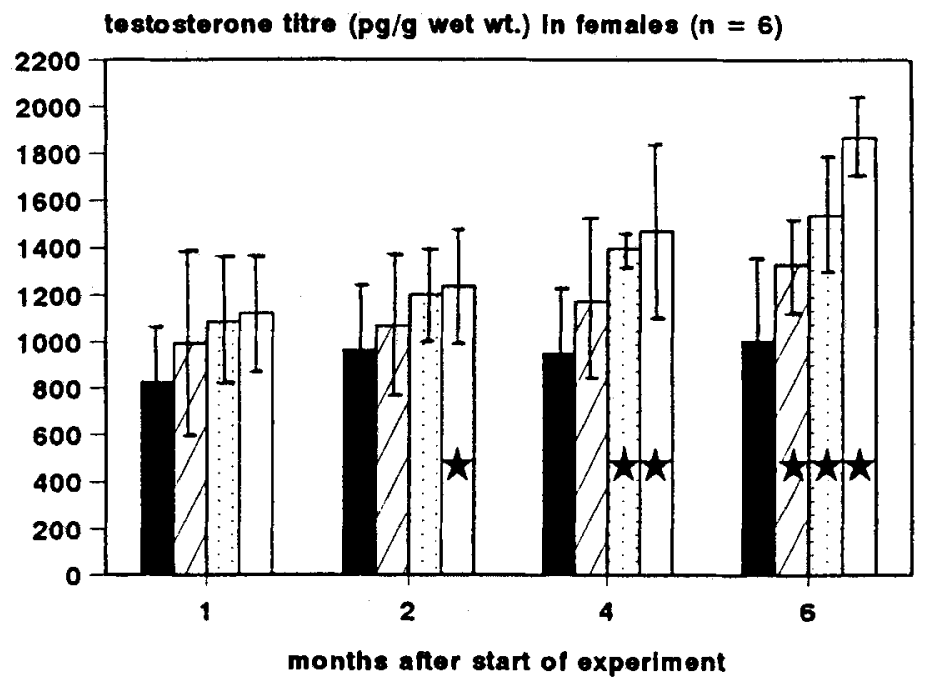

b

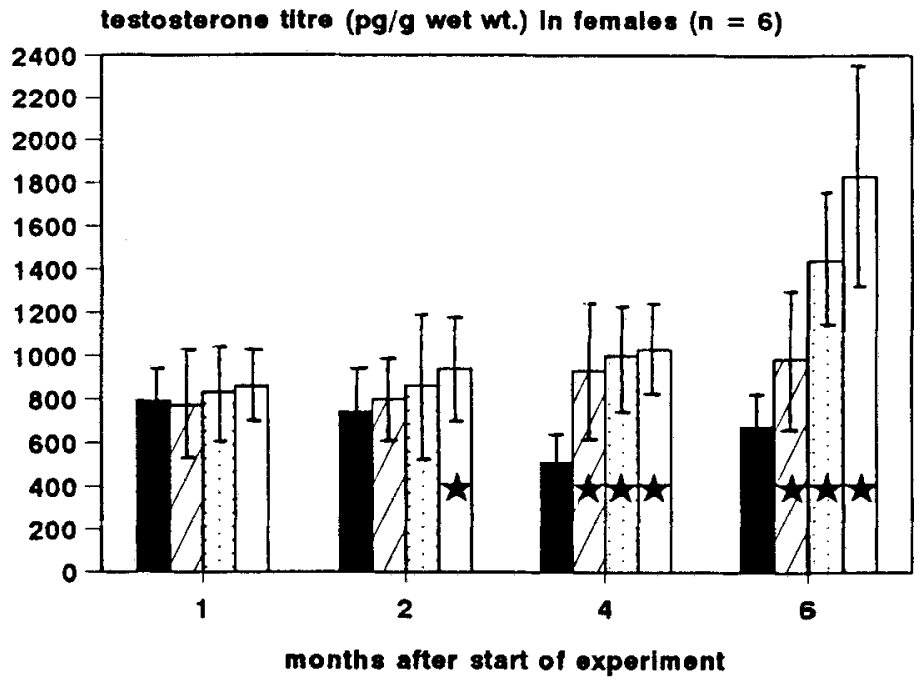

Fig. 3. The effect of TBT exposure on the endogenous testosterone titres in female Nucella lapillus (a) and female Hinia reticulata (b). control; 잘 $5 \mathrm{ng}$ TBT as Sn/1; 圈 $50 \mathrm{ng}$ TBT as Sn/l; $\square 100 \mathrm{ng}$ TBT as $\mathrm{Sn} / \mathrm{l}$. 'Significantly different at $\mathrm{p}<0.01$ versus control by Student's t-test $(n=6)$

Previous results suggest the involvement of androgens in the imposex development in marine neogastropods, but give no evidence that the effects of TBT are induced either directly in the organism or are mediated by an increasing androgen level. To gain this proof, the snails were simultaneously exposed to a TBT concentration of $50 \mathrm{ng}$ as $\mathrm{Sn} / \mathrm{l}$ and to the antiandrogen cyproterone acetate which is a competitive inhibitor of androgen receptors (Fig. 5). Imposex development is completely suppressed in N. lapillus. In 
a

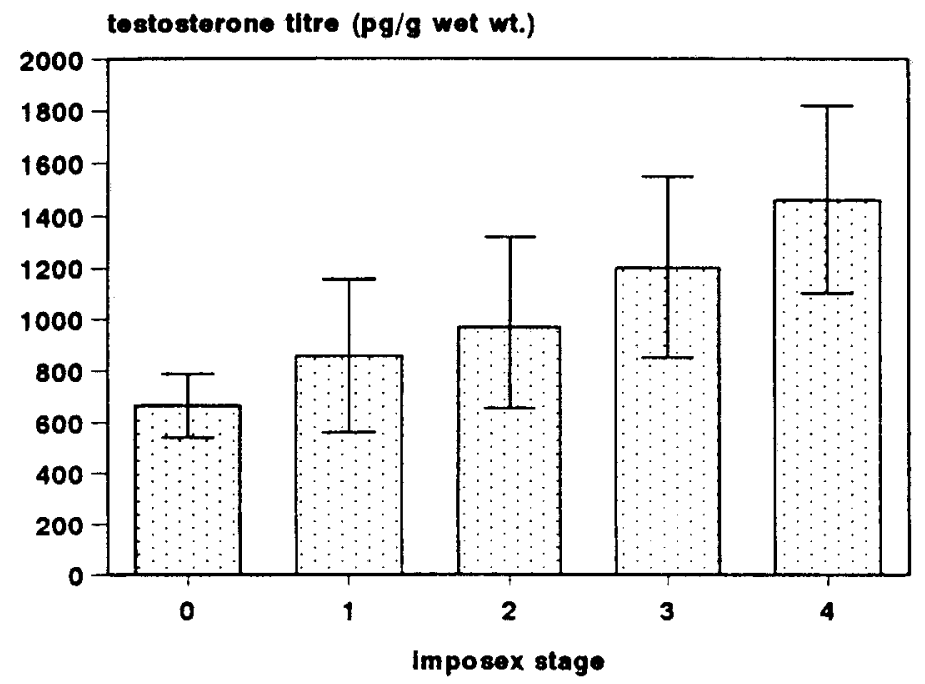

b

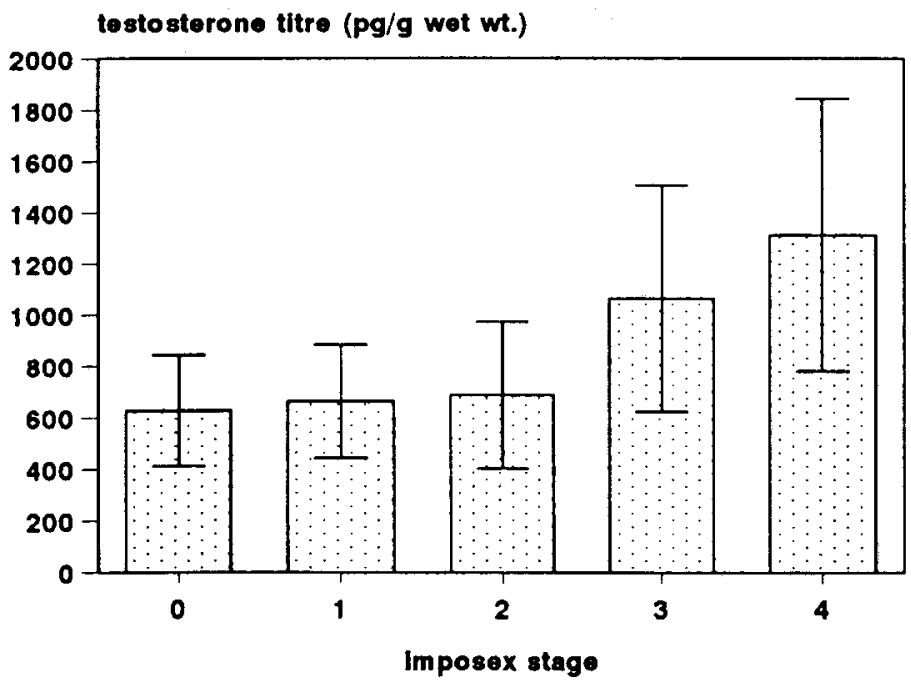

Fig. 4. Testosterone titres in the different imposex stages of female Nucella lapillus (a) and female Hinia reticulata (b). The values for the single stages are with the exception of stage 0 versus stage 1 in $H$. reticulata significantly different from each other (Student's t-test; $p<0.01$, in $N$. lapillus stage 0 : $\mathrm{n}=13 ;$ stage $1: \mathrm{n}=16 ;$ stage $2: \mathrm{n}=53$; stage $3: \mathrm{n}=53$; stage $4: \mathrm{n}=105$; in $H$. reticulata stage $0: n=29 ;$ stage $1: n=25$; stage $2: n=27$; stage $3: n=138 ;$ stage $4: n=36$ )

female $H$. reticulata, penis growth is also entirely suppressed, whereas the increase of the VDS index is only reduced but not completely blocked.

The distinct reaction of both snails may be attributed to a species-specific content of androgens and to a different androgen sensitivity of various tissues in each species. 

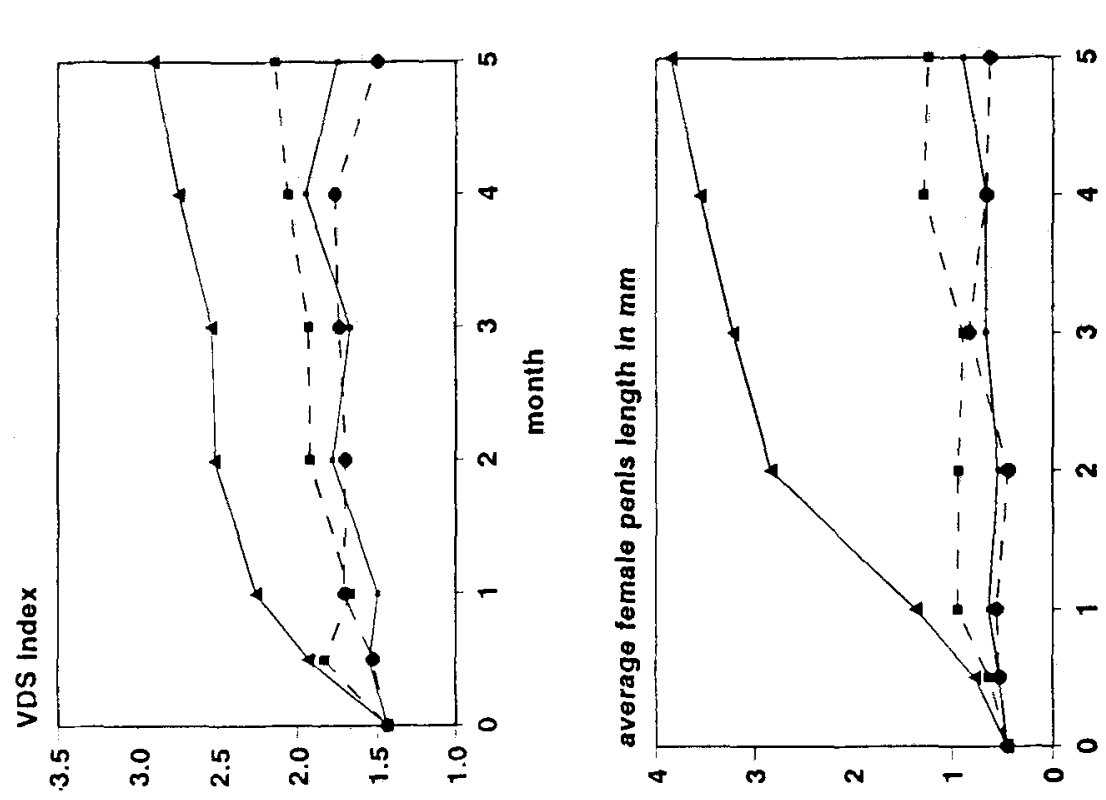

-

눈

范

.

ह

을

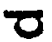
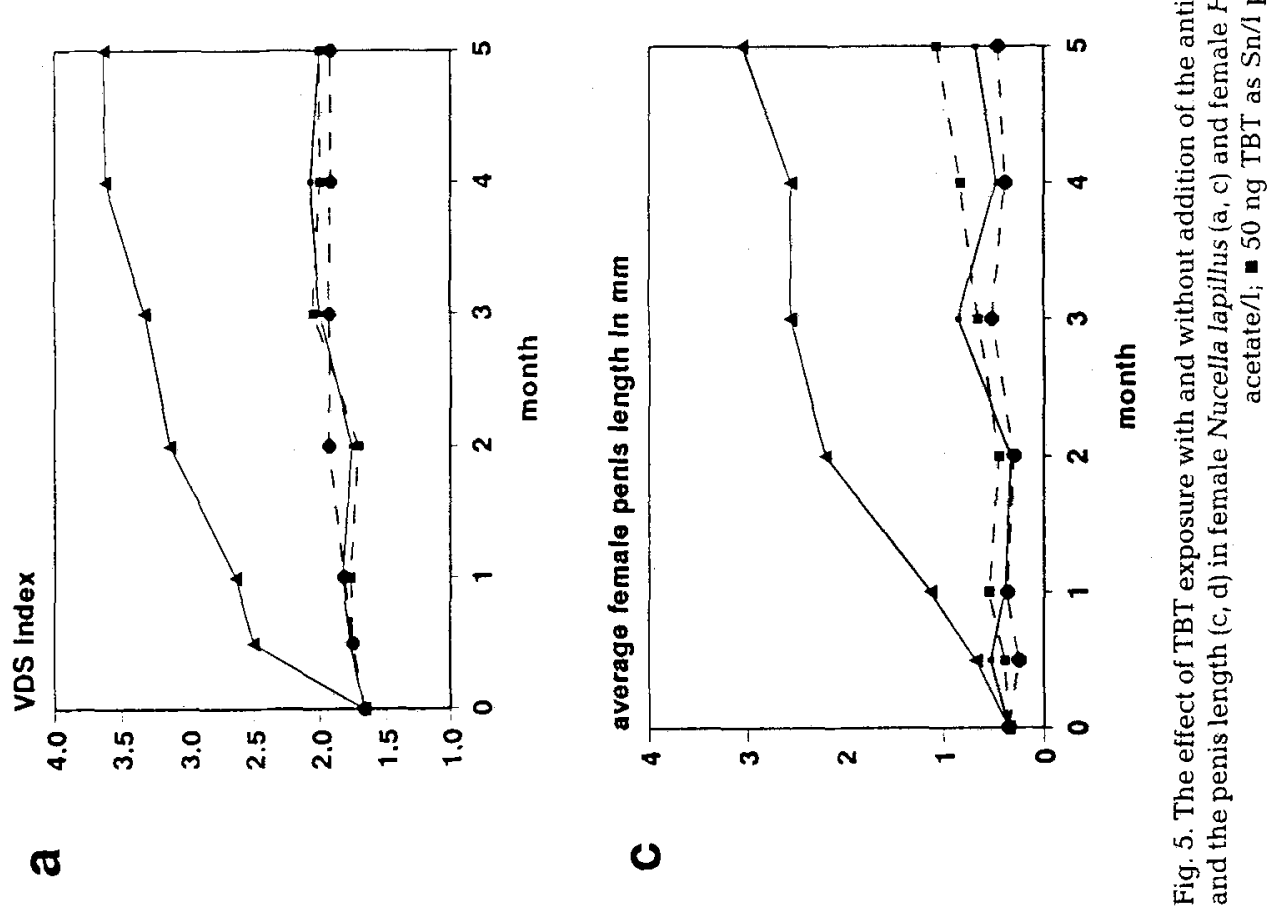

(

范

运

ह 응

ह 눙

g

in

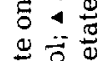

ఫ

\%

它宁苛

造

을

ठิํㅕㄱ

苞

을

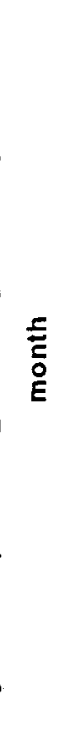

(⿻)

몸멸 
Although the measured testosterone levels are almost in the same range, the concentration of the endogenous androstenedione may possibly be higher in $H$. reticulata than in $N$. lapillus. Androstenedione, one of the male sex hormones, can be aromatized to estrogens by molluscs (Le Guellec et al., 1987) and was detected beside progesterone, testosterone, 17ß-estradiol, estrone and estriol in H. reticulata by HPLC and radioimmunoassay (Bettin, unpublished results). Androgen action in androgen-sensitive tissues requires the presence of androgen receptors to mediate transcriptional activation. A different regional distribution and intensity of androgen receptors among the target tissues may lead to a different reaction, although the tissues are exposed to the same androgen concentration. In both alternatives, higher androgen content and/or higher androgen sensitivity of special tissues, the added amount of cyproterone acetate was not sufficient in $H$. reticulata to block all androgen receptors. The lack of androgen receptors in distinct tissues might be the reason for low or missing imposex development in some gonochoristic prosobranch species, although their natural environment suffers from high TBT pollution.

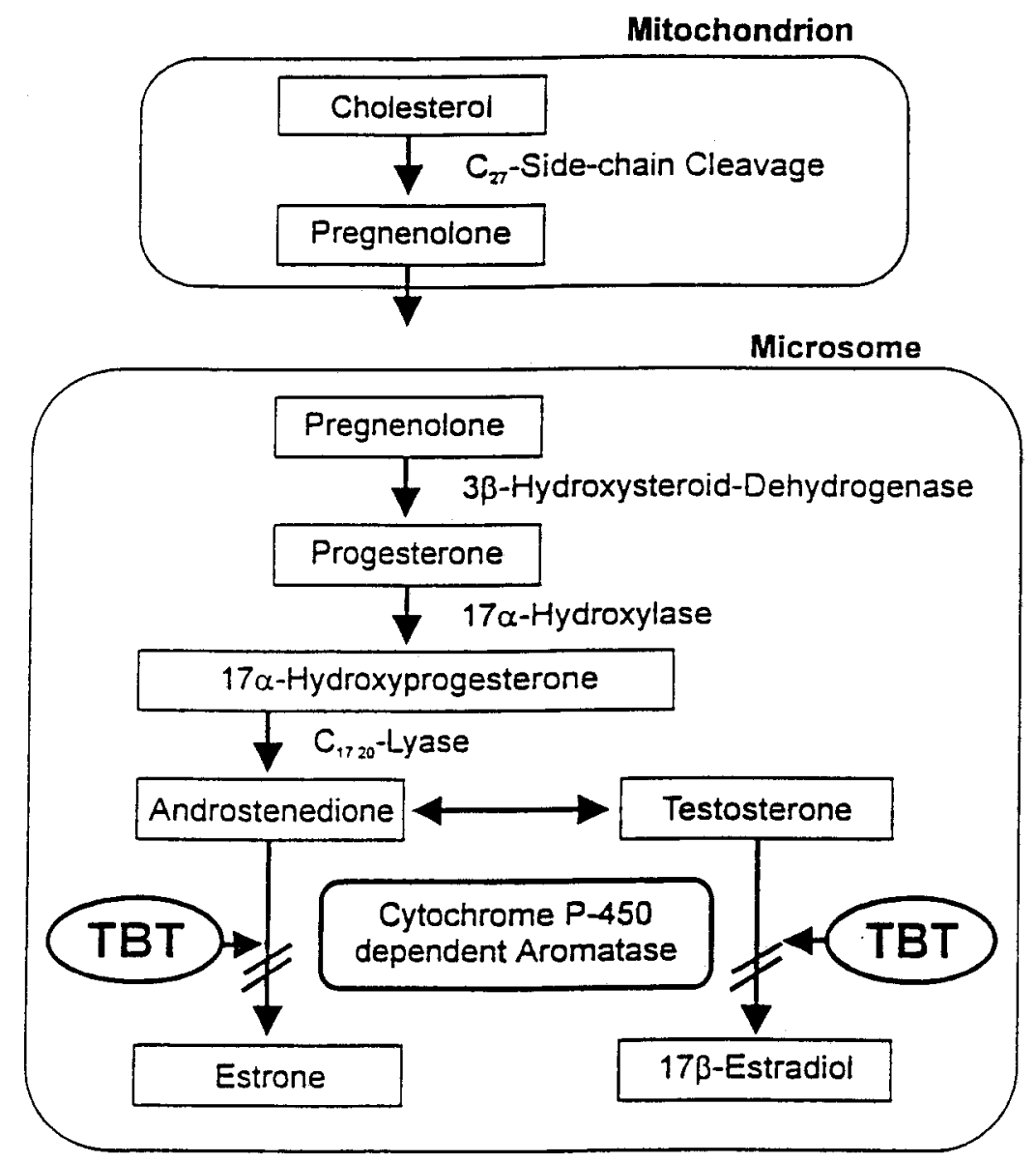

Fig. 6. Scheme of biosynthesis of steroid hormones with possible target of TBT 
The results of this experiment prove that the imposex-inducing effects of TBT are mediated by an increasing androgen level and are not caused directly by the organotin compound itself.

The present studies suggest that TBT disturbs the biosynthesis of steroid hormones by inhibiting the aromatization of the androgens androstenedione and testosterone to the estrogens estrone and 17ß-estradiol (Fig. 6). Steroid hormones, which have been detected in various organs of mollusc species, control both the development and the function of gonads and accessory sex glands as well as the sexual behaviour during the reproductive cycle (cf. Joosse, 1984; Joosse \& Geraerts, 1983). Investigations on the gonad tissue of some molluscs have demonstrated that steroidogenesis takes place by following a pathway very similar to that found in vertebrates (De Longcamp et al., 1974; Lupo di Prisco \& Dessi'Fulgheri, 1975). In vertebrates and many invertebrates, including molluscs, a multifunctional oxygenase (MFO) system exists which catalyses the conversion of androgens to estrogens (Kirchin et al., 1988; Livingstone et al., 1989, 1990; Payne et al., 1991). The same MFO system is believed to be responsible for the TBT debutylation (Lee, 1985, 1986). We presume that TBT leads to a competitive inhibition of the cytochrome P-450 dependent aromatase and consequently to an increase in the androgen level.

It could be expected that an increase of the androgen content and/or a change of the androgen-estrogen balance in favour of the androgens induces the development of pseudohermaphroditism. To verify this hypothesis, the gastropods were simultaneously exposed to TBT at a concentration of $50 \mathrm{ng}$ as $\mathrm{Sn} / \mathrm{l}$ and to an estrogen mixture containing $500 \mathrm{ng} / \mathrm{l} 17$-estradiol and $500 \mathrm{ng} / \mathrm{l}$ estrone (Fig. 7). The added estrogens suppress TBTinduced imposex development in both gastropod species. In $N$. lapillus an increase of the VDS index and in $H$. reticulata an increase of the female penis length are completely prevented, whereas the female penis growth in the dogwhelk and the increase of the VDS index in Hinia are strongly reduced.

In $N$. lapillus no significant change was measured in the endogenous $17 \beta$-estradiol content during exposure to TBT at a concentration from 5 to $50 \mathrm{ng}$ as $\mathrm{Sn} / \mathrm{l}$, whereas in $H$. reticulata rising $17 \beta$-estradiol levels were found in all TBT exposure groups compared to the control group after 4 months (Fig. 8). For the development of pseudohermaphrodi-

Table 1. Effect of testosterone exposure $(500 \mathrm{ng} / \mathrm{l})$ on the TBT (tributyltin) and DBT (dibutyltin) body burden in female Nucella lapillus and female Hinia reticulata

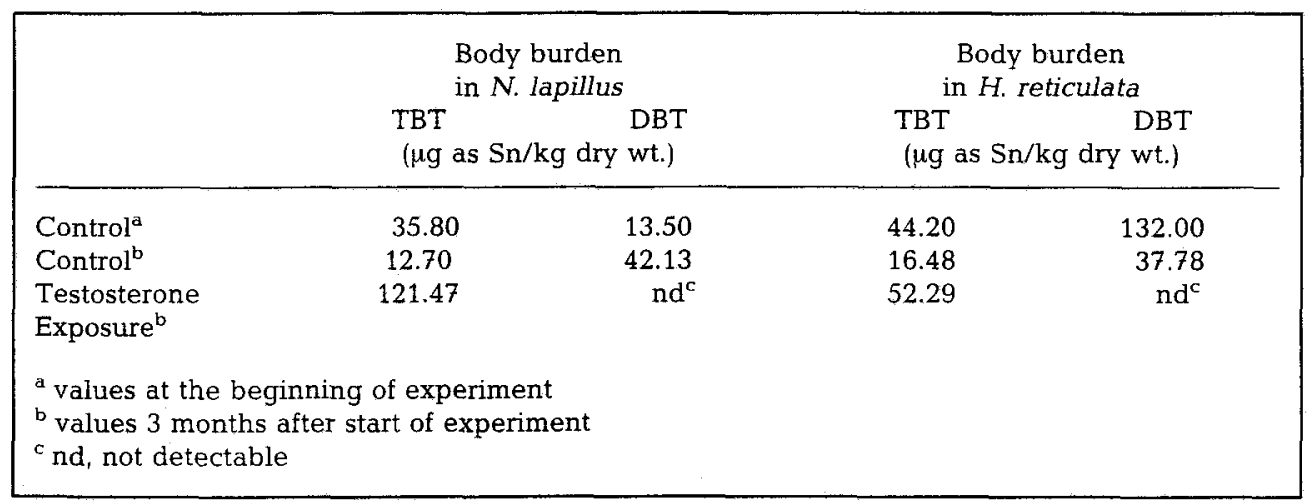


TBT-induced imposex in snails
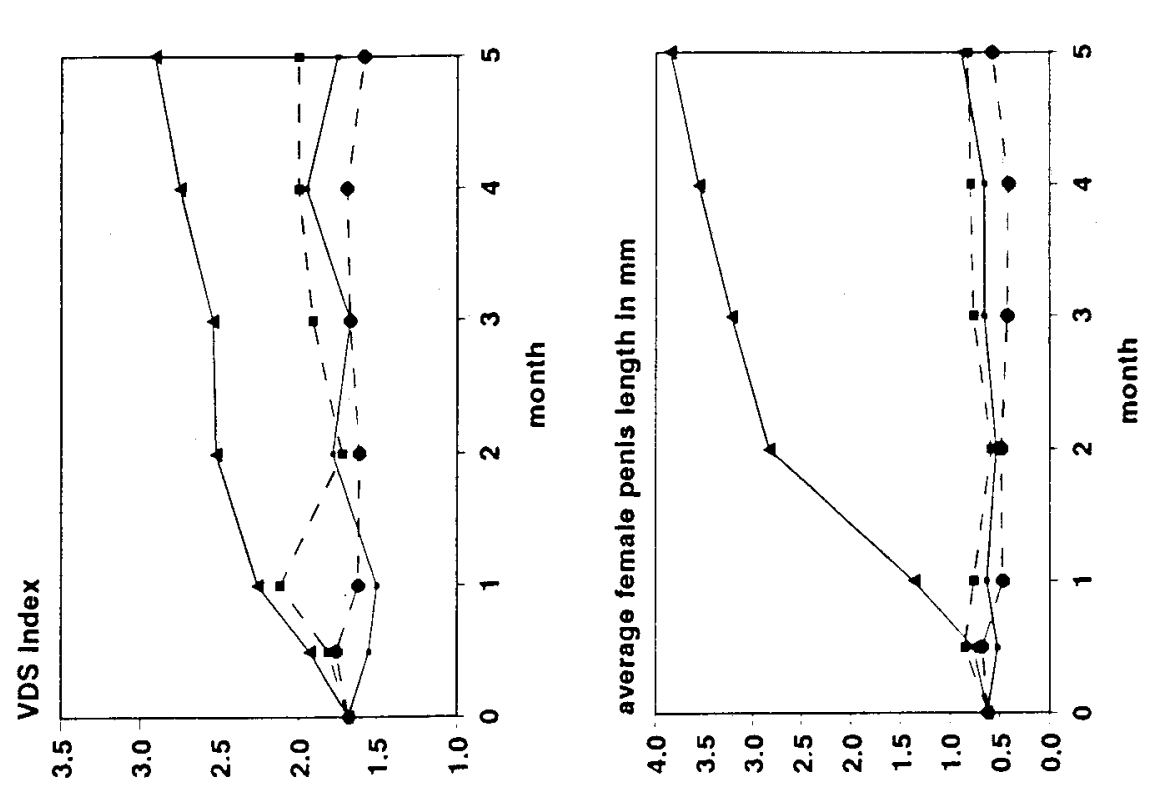

$\nabla \dot{\nabla}$

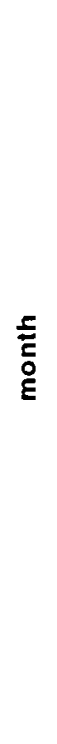

ㅇ

0
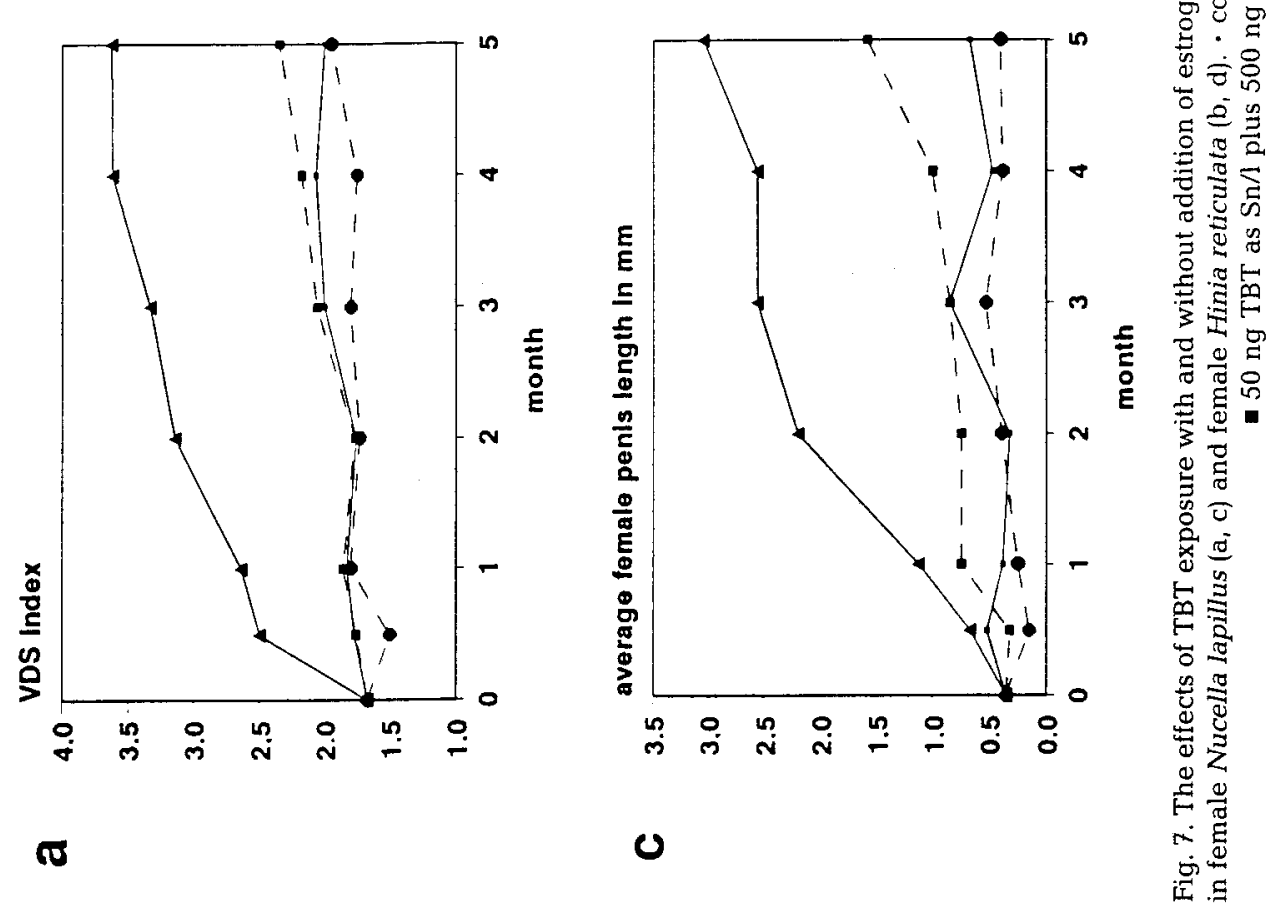

岳豆

क

용

记

ขृ

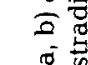

d

这

需

38

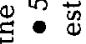

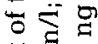

越的

홍

웡

迨贾

व

뭉 
a

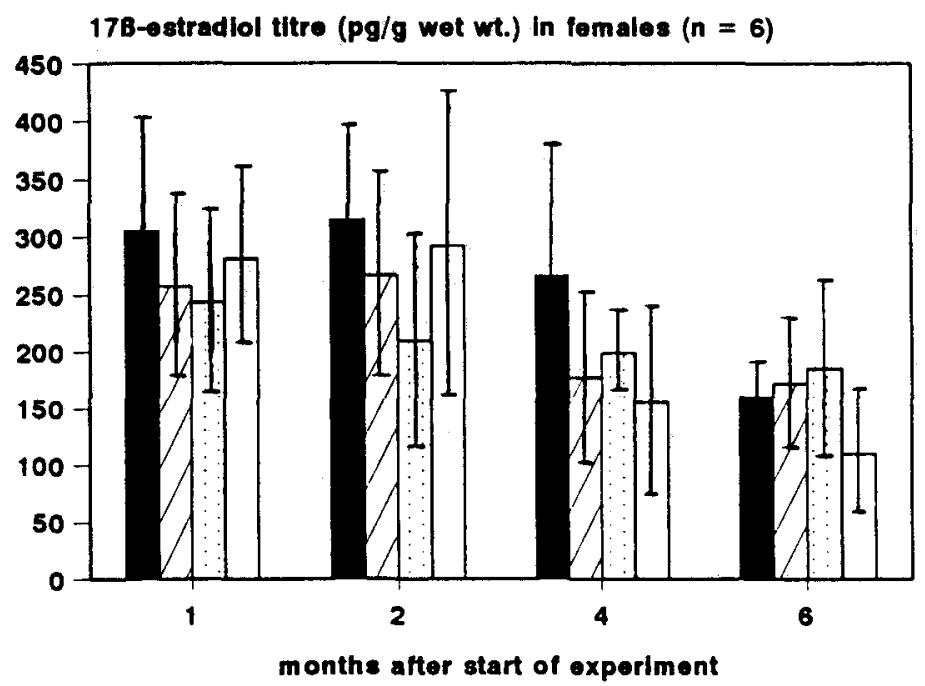

b

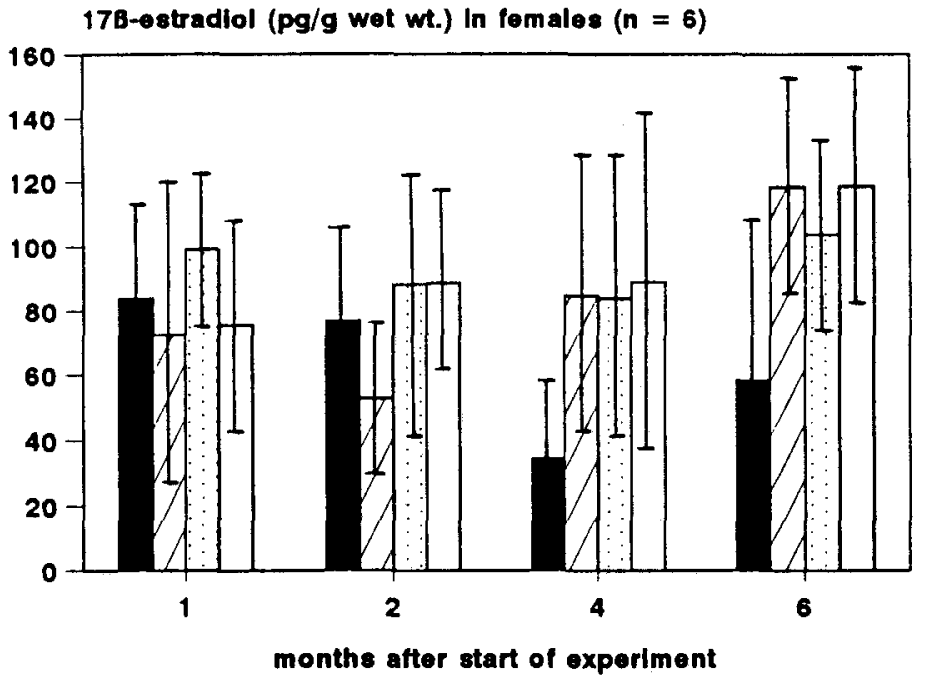

Fig. 8. The effect of TBT exposure on the endogenous $17 \beta$-estradiol titres in female Nucella lapillus (a) and female Hinia reticulata (b). control; $5 \mathrm{ng} \mathrm{TBT}$ as $\mathrm{Sn} / \mathrm{l}_{i}$, $50 \mathrm{ng} \mathrm{TBT}$ as $\mathrm{Sn} / \mathrm{l}_{\text {; }}$ $\square 100 \mathrm{ng} \mathrm{TBT}$ as $\mathrm{Sn} / \mathrm{l}$

tism, a special threshold value of androgens or an alteration of the androgen-estrogen relation might be important. In $N$. lapillus, the ratio of testosterone to $17 \beta$-estradiol increases from $6: 1$ in unaffected animals to $17: 1$ in snails exposed for 6 months to $100 \mathrm{ng}$ TBT as Sn/l (Fig. 9). In $H$. reticulata, a significant change in the testosterone-17 $\beta$-estradiol ratio is not observed. In this mollusc species, the main steroids may be androstenedione and estrone, which were not selected for monitoring in this study. 
a

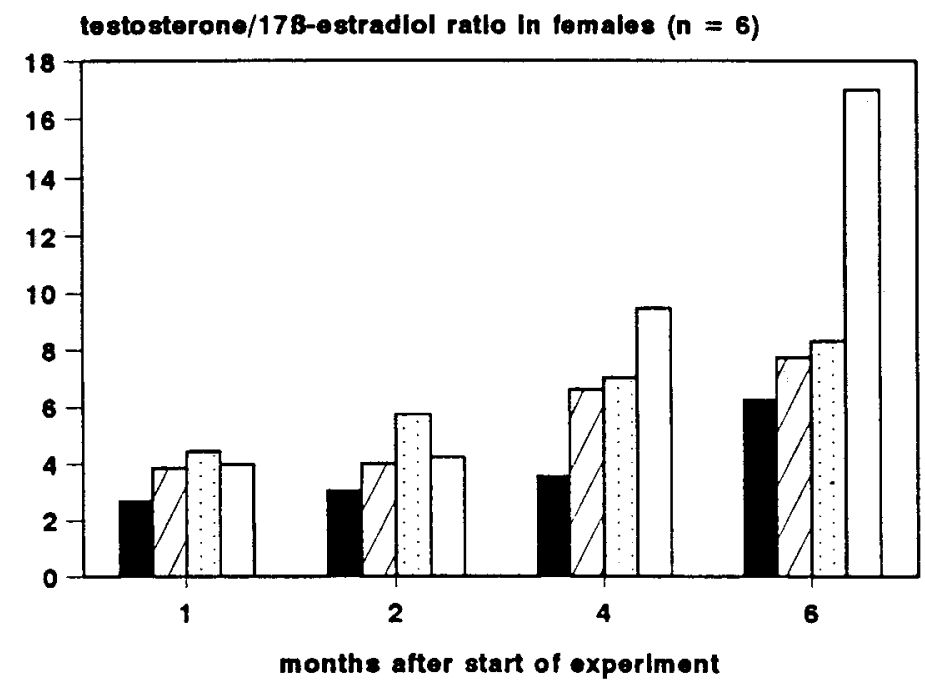

b

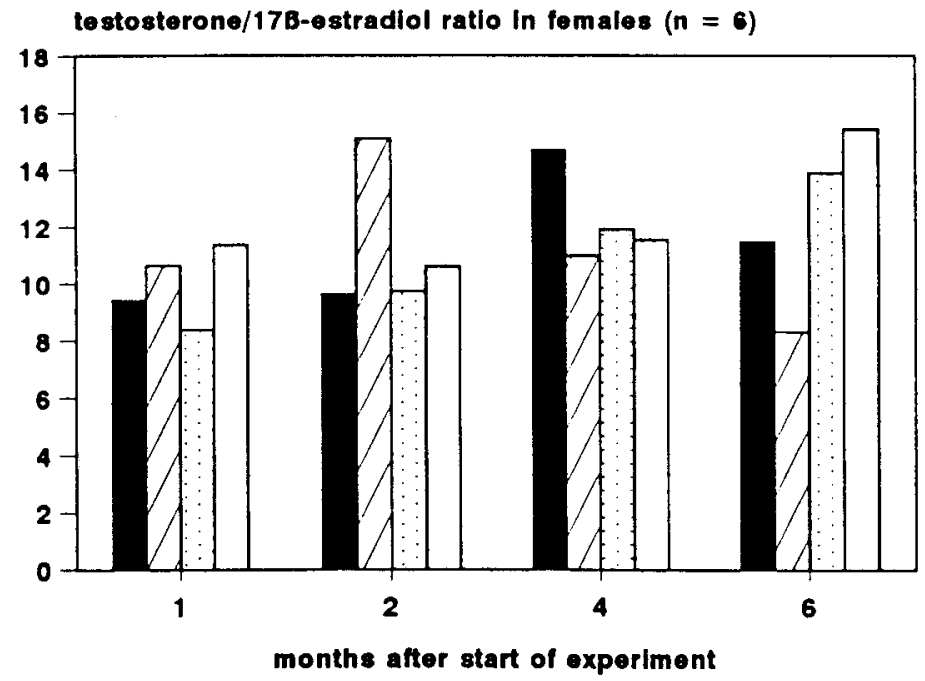

Fig. 9. The effect of TBT exposure on the ratio of testosterone to $17 \beta$-estradiol in female Nucella lapillus (a) and female Hinia reticulata (b). control; 圈 $5 \mathrm{ng}$ TBT as Sn/1; $50 \mathrm{ng} \mathrm{TBT}$ as $\mathrm{Sn} / 1$; $\square 100 \mathrm{ng}$ TBT as $\mathrm{Sn} / 1$

Further evidence of a competitive inhibition of the cytochrome P-450 dependent aromatase system by the organotin compound was provided by the determination of the endogenous content of TBT and its debutylation product DBT in those snails exposed to testosterone at a concentration of $500 \mathrm{ng} /$. During this experiment, $N$. lapillus and H. reticulata show an increase of endogenous TBT content and a decrease of the debutylation product $\mathrm{DBT}$, whereas the controls show a continuous TBT debutylation. No 

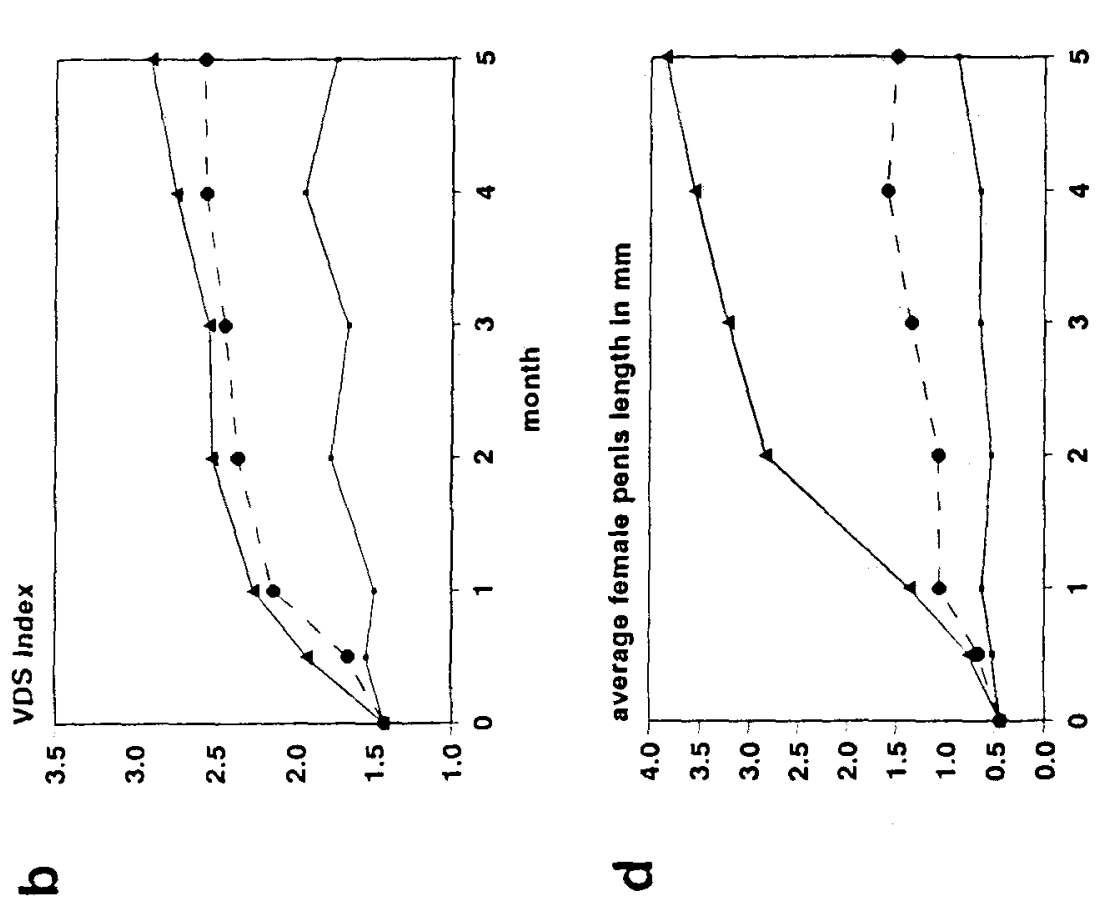

$\stackrel{\Phi}{\leftrightarrows}$

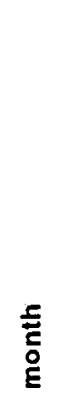

อ
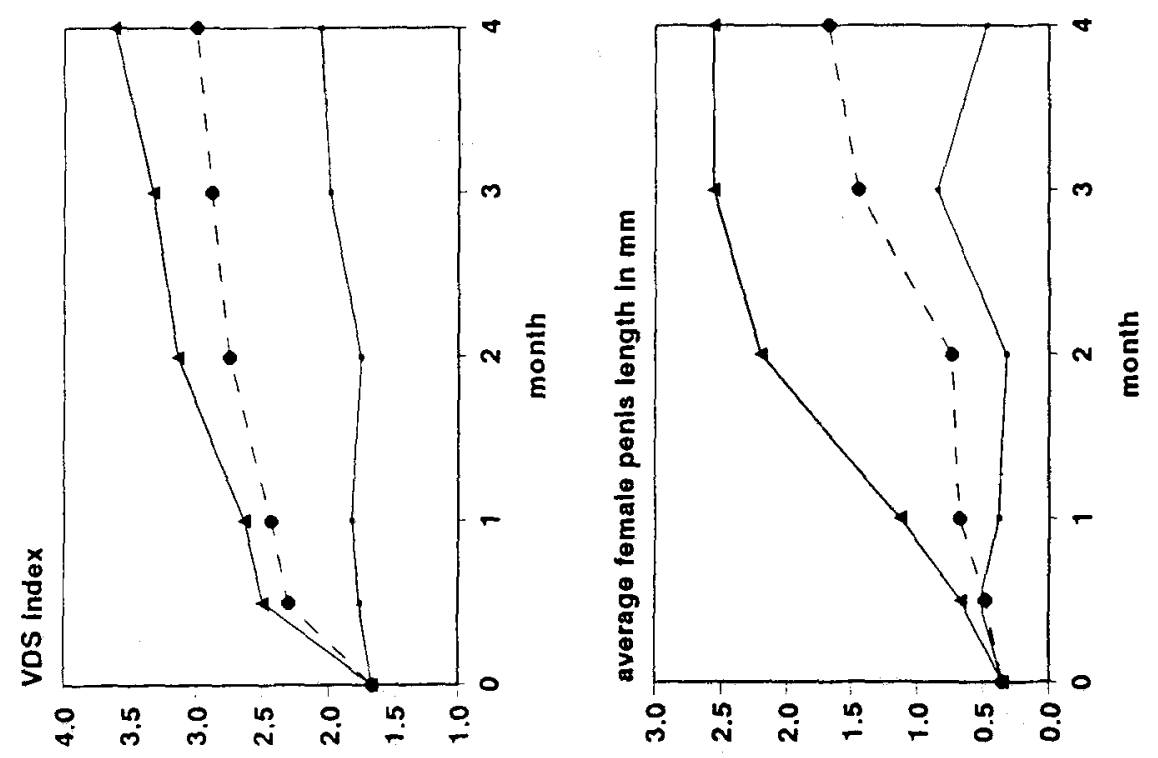

60

0 要窝 象

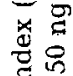
要 됼 다요

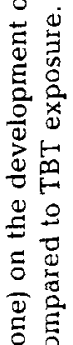
总

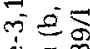

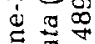
新

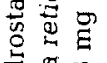
흘 궁 女.

空 包 吉 \% 完 西菍 范 票 要 常 $\frac{0}{\pi}$ 品 $\Xi \frac{5}{0}$ 0 总 ○ 䍃言 
DBT could be detected in animals of either snail species that had been exposed for three months to testosterone; this indicates that TBT degradation had ceased (Table 1).

The low TBT body burden in the experimental control snails is due to the background TBT pollution of their original biotope. TBT accumulation in the gastropods is also caused by TBT pollution of the supplied food (mussels and barnacles containing $12.8 \pm 9.3 \mu \mathrm{g}$ TBT as Sn/kg dry wt.; $\mathrm{n}=8$ ). But in neither mollusc species is the low accumulated endogenous TBT concentration able to induce advanced imposex stages. The results of these experiments suggest that due to the different concentrations of both substrates which are metabolized by the cytochrome P-450 dependent aromatase - a high endogenous testosterone and a low endogenous TBT content - the balance of metabolism is displaced in the direction of testosterone aromatization with the effect of decreasing TBT debutylation.

If TBT inhibits the aromatization of androgens, specific aromatase inhibitors should also be able to induce imposex. In a further experiment, the effects of the specific steroidal aromatase inhibitor SH 489 (1-methyl-1,4-androstadiene-3,17-dione) were compared to a solvent control and to a TBT exposure group with $50 \mathrm{ng}$ TBT as $\mathrm{Sn} / \mathrm{l}$ (Fig. 10). As expected, the specific aromatase inhibitor shows the same imposex-inducing effect as a TBT-exposure. Both $N$. lapillus and $H$. reticulata demonstrate increasing VDS indices, and in both snails the average female penis length is significantly greater than in the control. Imposex-inducing effects were also obtained in both mollusc species by using flavone in a concentration of $2.7 \mathrm{mg} / \mathrm{l}$ seawater as a non steroidal aromatase inhibitor (Ibrahim \& Abul-Hajj, 1990). Because of the lethal effects of the non specific aromatase inhibitor flavone, these experiments have to be suspended after three months exposure (data not shown).

The present studies suggest that TBT inhibits aromatization by competing with androstenedione and testosterone for the substrate binding sites of the cytochrome P-450 dependent aromatase. The resulting increase of androgens which causes an alteration of androgen-estrogen balance induces the development of pseudohermaphroditism in marine prosobranchs. Further biochemical studies on the structural elucidation of the aromatase active sites may be helpful in delineating the mechanism of action of the TBT aromatase inhibition.

Acknowledgements. The authors thank Schering AG (Berlin) for financial support and Prof. F. H. Kemper, Prof. H.-P. Bertram and Dr. C. Müller for the possibility to carry out the organotin analysis at the Environmental Specimen Bank for Human Tissue, Münster.

\section{LITERATURE CITED}

Blaber, S. J. M., 1970. The occurrence of a penis-like outgrowth behind the right tentacle in spent females of Nucella lapillus (L.). - Proc. malac. Soc. Lond. 39, 231-233.

Bryan, G. W., Gibbs, P. E., Huggett, R. J., Curtis, L. A., Bailey, D. S. \& Dauer, D. M., 1989. Effects of tributyltin pollution on the mud snail, Ilyanassa obsoleta, from York River and Sarah Creek, Chesapeake Bay. - Mar. Pollut. Bull. 20, 458-462.

Cardwell, R. D. \& Sheldon, A. W., 1986. A risk assessment concerning the fate and effects of tributyltins on the aquatic environment. In: Oceans ' 86 Conference Record. Vol. 4; Organotin Symposium, Washington, D.C. IEEE Service Center, Piscataway, N.J., 1117-1129.

Chagot, D., Alzieu, C., Sanjuan, J. \& Grizel, H., 1990. Sublethal and histopathological effects of trace 
levels of tributyltin fluoride on adult oysters Crassostrea gigas. - Aquat. living Resour. 3, $121-130$.

De Longcamp, D., Lubet, P. \& Drosdowsky, M., 1974. The in vitro biosynthesis of steroids by the gonad of the mussel (Mytilus edulis). - Gen. comp. Endocrnol, 22, 116-127.

Evans, D. W. \& Laughlin, R. B., 1984. Accumulation of bis(tributyltin) oxide by the mud crab, Rhithropanopeus harrasii. - Chemosphere 13, 213-219.

Fent, K., 1991. Bioconcentration and elimination of tributyltin chloride by embryos and larvae of minnows Phoxinus phoxinus. - Aquat. Toxicol. 20, 147-158.

Fent, K. \& Meier, W., 1992. Tributyltin-induced effects on early life stages of minnows Phoxinus phoxinus. - Archs environ. Contam. Toxicol. 22, 428-438.

Féral, C., 1974. Etude comparée des populations d'Ocenebra erinacea (L.) de Granville et d'Arcachon. - Haliotis 4, 123-134.

Féral, C., 1976a. Étude statistique de la présence d'un tractus génital mâle externe chez les femelles d'un Mollusque Gastéropode gonochorique: Ocenebra erinacea (L.). - Cah. Biol. mar. 17, 61-76.

Féral, C., 1976b. Analyse expérimental de la morphogenèse et du cycle du pénis chez les femelles d'Ocenebra erinacea, espèce gonochorique. - Haliotis 6, 267-271.

Féral, C., 1976c. Répartition géographique des femelles à tractus génital mâle externe chez Ocenebra erinacea (L.), espèce gonochorique. - Haliotis 7, 29-30.

Féral, C., 1980. Variations dans l'évolution du tractus génital mâle externe des femelles de trois Gasteropodes Prosobranches gonochoriques de stations atlantiques. - Cah. Biol. mar. 21, $479-491$.

Féral, C. \& Le Gall, S., 1983. The influence of a pollutant factor (tributyltin) on the neuroendocrine mechanism responsible for the occurrence of a penis in the females of Ocenebra erinacea. In: Molluscan neuro-endocrinology. Ed. by J. Lever \& H. H. Boer. North-Holland Publ. Comp., Amsterdam, 173-175.

Fioroni, P., Oehlmann, J. \& Stroben, E., 1991. The pseudohermaphroditism of prosobranchs; morphological aspects. - Zool. Anz. 226, 1-26.

Gibbs, P. E. \& Bryan, G. W., 1986. Reproductive failure in populations of the dog-whelk, Nucella lapillus, caused by imposex induced by tributyltin from antifouling paints. - J. mar. biol. Ass. U.K. $66,767-777$.

Gibbs, P. E. \& Bryan, G. W., 1987. TBT paints and the demise of the dog-whelk, Nucella lapillus (Gastropoda). In: Oceans '87 Conference Record. Vol. 4: Organotin Symposium, Halifax, Nova Scotia. IEEE Service Center, Piscataway, N.J., 1482-1487.

Gibbs, P. E., Bryan, G. W., Pascoe, P. L. \& Burt, G. R., 1987. The use of the dog-whelk, Nucella lapillus, as an indicator of tributyltin (TBT) contamination. - J. mar. biol. Ass. U.K. 67, 507-523.

Gibbs, P. E., Pascoe, P. L. \& Burt, G. R., 1988. Sex change in the female dog-whelk, Nucella lapillus, induced by tributyltin from antifouling paints. - J. mar. biol. Ass. U.K. 68, 715-731.

Hall, L. W. \& Pinkney, A. E., 1985. Acute and sublethal effects of organotin compounds in aquatic biota: an interpretative literature evaluation. - CRC crit. Rev. Toxicol. 14, 159-209.

Henderson, D., 1987. Aromatase inhibitors: their biochemistry and clinical potential. - J. Steroid Biochem. 27, 905-914.

Ibrahim, A.-R. \& Abul-Hajj, Y. J., 1990. Aromatase inhibition by flavonoids. - J. Steroid Biochem. molec. Biol. 37, 257-260.

Jenner, M. G., 1979. Pseudohermaphroditism: a newly recognized sexual phenomenon in Ilyanassa obsoleta and other Neogastropoda. - Diss. Abstr. int. 40B, 117.

Joosse, J., 1984. Recent progress in endocrinology of molluscs. In: Biosynthesis, metabolism and mode of action in invertebrate hormones. Ed. by J. Hoffmann \& M. Porchet. Springer, Berlin, 19-35.

Joosse, J. \& Geraerts, W. P. M., 1983. Endocrinology. In: The Mollusca. Ed. by A. S. M. Saleuddin \& K. M. Wilbur, Acad. Press, London, 4, 317-406.

Kirchin, M. A., Wiseman, A. \& Livingstone, D. R., 1988. Studies on the mixed-function oxygenase system of the marine bivalve Mytilus edulis. - Mar. environ. Res. 24, 117-118.

Langston, W. J., Burt, G. R. \& Mingjiang, Z., 1987. Tin and organotin in water, sediments, and benthic organisms of Poole Harbour. - Mar. Pollut. Bull. 18, 634-639.

Laughlin, R. B., French, W. \& Guard, H. E., 1986. Accumulation of bis(tributyltin) oxide by the marine mussel Mytilus edulis. - Environ. Sci. Technol. 20, 884-890. 
Lee, R. F., 1985. Metabolism of tributyltin oxide by crabs, oysters and fish. - Mar. environ. Res. 17, $145-148$.

Lee, R. F., 1986. Metabolism of bis(tributyltin)oxide by estuarine animals. In: Oceans '86 Conference Record. Vol, 4: Organotin Symposium, Washington, D.C. IEEE Service Center, Piscataway, N.J., 1182-1188.

Le Guellec, D., Thiard, M.-C., Remy-Martin, J. P., Deray, A., Gomot, L. \& Adessi, G. L., 1987. In vitro metabolism of androstenedione and identification of endogenous steroids in Helix aspersa. Gen. comp. Endocrinol. 66, 425-433.

Livingstone, D. R., Arnold, R., Chipman, K., Kirchin, M. A. \& Marsh, J., 1990. The mixed-function oxygenase system in molluscs: metabolism, responses to xenobiotics and toxicity. - Océanis 16 , $331-347$.

Livingstone, D. R., Kirchin, M. A. \& Wiseman, A., 1989. Cytochrome P-450 and oxidative metabolism in molluscs. - Xenobiotica 19, 1041-1062.

Lupo di Prisco, C. \& Dessi'Fulgheri, F., 1975. Alternative pathways of steroid biosynthesis in gonads and hepatopancreas of Aplysia depilans. - Comp. Biochem. Physiol. 50B, 191-195.

Martin, R. C., Dixon, D. G., Maguire, R. J., Hodson, P. V. \& Tkacz R. J., 1989. Acute toxicity, uptake, depuration and tissue distribution of tri-n-butyltin in rainbow trout, Salmo gairdneri. - Aquat. Toxicol. 15, 37-52.

Oehlmann, J., Stroben, E. \& Fioroni, P., 1991. The morphological expression of imposex in Nucella Iapillus (Linnaeus) (Gastropoda: Muricidae), - J. moll. Stud. 57, 375-390.

Oehlmann, J., Stroben, E. \& Fioroni, P., 1992. The rough tingle Ocenebra erinacea (Gastropoda: Muricidae): an exhibitor of imposex in comparison to Nucella lapillus. - Helgoländer Meeresunters. $46,311-328$.

Oehlmann, J., Stroben, E. \& Fioroni, P., 1996. Tributyltin (TBT) effects on Ocinebrina aciculata (Gastropoda: Muricidae): imposex development, sterilization, sex change and population decline. - Zool. Anz. (In press).

Payne, E., Smith, J. F., Cope, B. C. \& McGowan, L. T., 1991. Studies on the role of liver cytochrome P-450 and oestradiol metabolism in the effects of nutrition and phenobarbital on ovulation rate in the ewe. - Reprod. Fertil. Dev. 3, 725-736.

Smith, B. S., 1971. Sexuality in the American mud snail, Nassarius obsoletus Say. - Proc. malac. Soc. Lond. $39,377$.

Smith, B. S., 1980. The estuarine mud snail, Nassarius obsoletus: abnormalities in the reproductive system. - J. moll. Stud. 46, 247-256.

Smith, B. S., 1981a. Male characteristics in the female Nassarius obsoletus: variations related to locality, season and year. - Veliger 23, 212-216.

Smith, B. S., 1981b. Reproductive anomalies in stenoglossan snails related to pollution from marinas. - J. appl. Toxicol. 1, 15-21.

Smith, B. S., 1981c. Male characteristics on female mud snails caused by antifouling bottom paints. J. appl. Toxicol. 1, 22-25.

Smith, B. S., 1981d. Tributyltin compounds induce male characteristics on female mud snails Nassarius obsoletus = Ilyanassa obsoleta. $-\mathrm{J}$. appl. Toxicol. 1, 141-144.

Spooner, N., Gibbs, P. E., Bryan, G. W. \& Goad, L. J., 1991. The effect of tributyltin upon steroid titres in the female dogwhelk, Nucella lapillus, and the development of imposex. - Mar. environ. Res. $32,37-49$.

Stroben, E., Oehlmann, J. \& Bettin, C., 1991. TBT-induced imposex and the role of steroids in marine snails. In: Proceedings of the Tenth World Meeting ORganoTin Environmental Programme (ORTEP) Association, Berlin, September 26/27, 1991. Vissingen, ORTEP Ass., 68-73.

Stroben, E., Oehlmann, J. \& Fioroni, P., 1992a. The morphological expression of imposex in Hinia reticulata (Gastropoda: Buccinidae): a potential biological indicator of tributyltin pollution. Mar. Biol. 113, 625-636.

Stroben, E., Oehlmann, J. \& Fioroni, P., 1992b. Hinia reticulata and Nucella lapillus - comparison of two TBT bioindicators. - Mar. Biol. 114, 289-296.

Thain, J. E., 1986. Toxicity of TBT to bivalves; effects on reproduction, growth and survival. In: Oceans '86 Conference Record. Vol. 4: Organotin Symposium, Washington, D.C. IEEE Service Center, Piscataway, N.J., 1306-1313.

Thain, J. E. \& Waldock, M. J., 1986. The impact of tributyltin (TBT) antifouling paints on molluscan fisheries. - Wat. Sci. Technol. 18, 193-202. 